\title{
Napier Grass (Pennisetum purpureum) versus Sugar- cane (Sacharum oficinarum) as Forage Crops in Puerto Rico
}

\author{
L. Rivera-Brenes, H. Cestero, and A. Sierra ${ }^{1}$
}

\section{INTRODUCTION}

Napier grass, known as Merker in Puerto Rico, is the best and highest yielding soilage grass now in use in the Island $(4,5)^{2}$, and it is very palatable (6). It rapidly recovers from harvest, permitting intervals of 60 days on the average, and less than that, 40 to 50 , during late spring and summer (8).

Sugarcane tops are used for forage during the sugarcane harvest season, which coincides with the dry period of the year. Some whole cane is used also as forage for cattle on a few farms.

A few years ago the sugarcane breeders at this Station observed that one of the seedlings exhibited good forage characteristics. It was leafy, the leaves were wide and tender, glabrous, and the stem or cane soft. They named it P.R 1010. After a period of observation it was turned over to the Animal Husbandry Department for further field and animal tests. First it was to be compared with Napier grass, which is our standard soilage grass.

Many farmers had consulted this Station directly or through the extension agents on the convenience of planting sugarcane solely for foragc. The results obtained in this experiment give them an answer.

\section{LITERATURE REVIEW}

Sugarcane tops are used for forage in Puerto Rico and in other places where grown $(1,2,7)$. The whole cane is also used as forage at all stages of growth (2). Alonso Olive (1), from Cuba, stated that both the tops and the whole cane were low in nutritive value and very inefficient for the production of milk or beef. Bregger and Kidder (2) recommended sugarcane as forage for southern Florida. Cane tops and young whole cane have been ensiled and used for milk production in Puerto Rico (3). No information has been found showing that sugarcane has been compared to other forage grasses as to yield per acre. The literature on the use of Napier grass for cattle feeding is extensive. There is much information on the response of

${ }^{1}$ Head, Animal Husbandry Department, Assistant Animal Husbandman, and Assistant Agronomist, Agricultural Experiment Station, University of Puerto Rico, Río Piedras, P.R.

2 Italic numbers in parentheses refer to Literature Cited, p. 312. 
this grass to fertilizer applications, yield per acre, silage, palatability, nutritive value, etc. $(4,5,6,8)$.

\section{PROCEDURE}

Both grasses were to be compared as to yield of green and dry matter per acre. The speed of recovery after harvesting of the sugarcane as compared to Napier was also investigated.

A block design with plots $20 \times 20$ feet replicated six times was followed with two cutting intervals of 60 and 90 days. Both grasses were planted at the same planting distance, i.e. 30 inches between rows.

The experiment was established at the Gurabo Substation in an eroded Mabi clay. An initial fertilizer application at the rate of 200 pounds of $N$, 50 pounds of $\mathrm{P}_{2} \mathrm{O}_{5}$, and 125 pounds of $\mathrm{K}_{2} \mathrm{O}$ per acre was made, as recommended by the Soils Department of this Station. It was followed by applications of $\mathrm{N}$ at the rate of 480 pounds per acre per year, divided into six equal parts for the 60-day cutting interval and into four equal parts for the 90 -day cutting interval.

After the first year of experiment the forage yields were considered lower than expected and the Soils Department recommended liming the plots and a heavier application of $\mathrm{P}_{2} \mathrm{O}_{5}$ and $\mathrm{K}_{2} \mathrm{O}$. One hundred pounds of lime was spread over each plot; superphosphate at the rate of 1,000 pounds per acre and muriate of potash at the rate of 500 pounds per acre were also applied. The same nitrogen applications as used the first year were made during the second.

All forage from each plot was cut and weighed at the corresponding interval. Composite samples of the six replicates were taken for dry-matter and crude-protein determinations. Official Methods were followed.

The data on yields of dry matter per acre were statistically analyzed.

The experiment was carried for 2 years.

\section{RESULTS AND DISCUSSION}

Total yields per acre for the experimental period and yields per acre per year are presented in the table 1. They are presented as pounds of green and dry matter and as tons of green matter per acre.

Statistical analysis was made for the total yields of dry matter for Napier grass and sugarcane at the two cutting intervals.

Dry-matter yield of Napier grass at the 60-day cutting interval was significantly higher at the 1-percent level than that of sugarcane at that same interval; it was also higher at the 5-percent level than the yield of sugarcane at the 90-day cutting interval. The yield of Napier at the 90-day cutting interval was significantly higher at the 1-percent level than the yield of the same grass at the 60-day cutting interval. No significant differ- 
ence was found between the yields of dry matter of sugarcane at the two cutting intervals.

Although the dry-matter yields per acre for both grasses were lower than expected, because of the poor soil in which the experiment was established, the differences between them were expected since we were dealing with two physiologically different grasses, a fast- and a slow-growing one.

When the experiment was planted, Napier grass was ready to be cut for the first time much sooner than sugarcane. When Napier was 5 feet high, sugarcane was only $11 / 2$ feet (fig. 1).

1 his was the case all the way through the experimental period. Napier gra is closed in very fast and the plots were completely closed 40 days after eutting, shatding out and smothering the weeds below. larmers know that

TABLE 1.- Tield per acre of . Vapier grass and forage sugarcane on green and dry basis when ewl at different intervals

\begin{tabular}{|c|c|c|c|c|c|c|}
\hline \multirow{2}{*}{ Grass and cuttings } & \multicolumn{3}{|c|}{ Results for the 2 years } & \multicolumn{3}{|c|}{ Average per year } \\
\hline & $\begin{array}{c}\text { Green } \\
\text { matter }\end{array}$ & $\underset{\text { matter }}{\text { Dry }}$ & $\begin{array}{c}\text { Green } \\
\text { matter }\end{array}$ & $\begin{array}{c}\text { Green } \\
\text { matter }\end{array}$ & $\underset{\text { matter }}{\text { Dry }}$ & $\begin{array}{c}\text { Green } \\
\text { matter }\end{array}$ \\
\hline & Pounds & Pounds & To:s & Pounds & Paunts & Tons \\
\hline Napicr, 60-day, 12 cuttings & 248,401 & 48,380 & 124.20 & 124,200 & 24,190 & 62.10 \\
\hline Napier, 90-day, 8 cuttings & 304,811 & 82,870 & 152.41 & 152,405 & 41,435 & 76.21 \\
\hline Sugarcane, 60-day, 12 cottings & 112,167 & 25.875 & 56.08 & 56,084 & 12,938 & 28.04 \\
\hline Sugarcane, 90-day, 8 cuttings & 155,836 & 36,913 & 77.92 & 77,918 & 18,456 & 38.93 \\
\hline
\end{tabular}

sugarcane needs more than 3 months to close in, giving plenty of time for weeds to grow abundantly, and not quickly producing a large amount of forage. Because of this particular characteristic in the growth habit of sugarcane we do not recommend farmers to plant sugarcane for forage when they can do much better with Napier grass.

In Puerto Rico land is very expensive and farmers cannot afford to have a forage grass like sugarcane to be harvested at most twice during the year to get a reasonable amount of forage, when Napier can be cut six or more times with considerable higher tomnage per acre, quality not considered. Napier is also easier to harvest, and its high yield makes greater efficiency possible by the cutters.

Table 2 presents the protein perentage on the dry basis for the two grasies at the two cutting intervals.

The grasses were equal, on the average, in protein content at the 60-day cutting interval, but sugareane was a little higher at the 90-day interval. This is becallse sugareane is slower in maturing. 
'The average yields of dry matter per plot and per year of experiment are presented in table 3.

It is very interesting to see the difference in yield of dry matter for the first and second years of the experiment. As was stated under Procedure, lime was applied beginning the second year of experiment, as well as larger amounts of phosphorous and potash. Yields were doubled the second year, as shown in table 3. These badly eroded soils can be corrected and made much more productive.

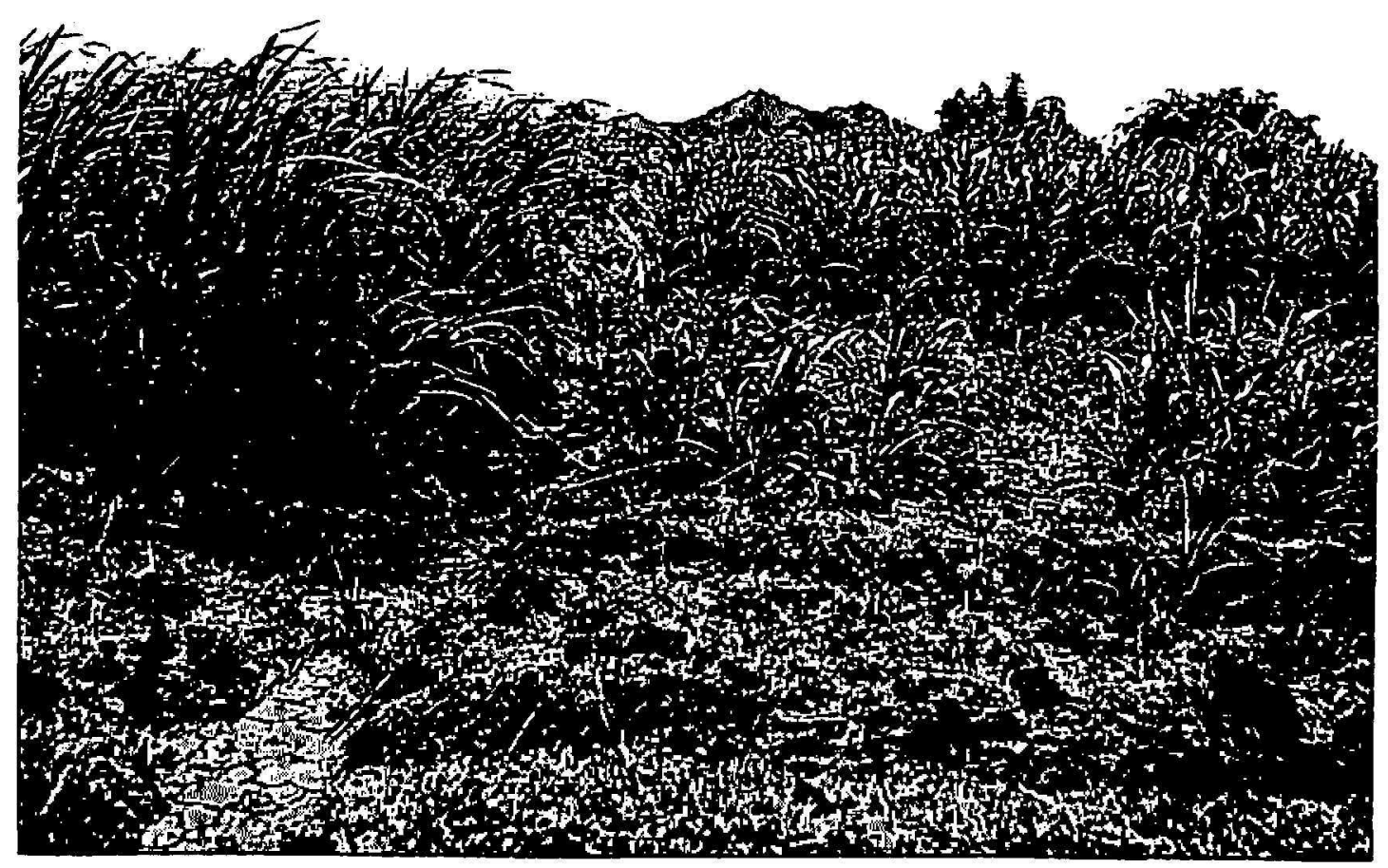

Frg. 1.-Napier Grass (left) and sugareane (right) between 40 and 50 days old. The difference in growth is obvious.

\section{SUMMARY ANI) RECOMMENDATIONS}

An experiment was carried out to test the forage productivity of the tops of a sugarcine variety, P.R. 1010, as compared with Napier grass (Merker). Two eutting intervals were followed, (i0- and 90-day. Sixty days is the average interval recommended for Napier.

Napier grass outyielded sugarcane significantly at the 1-percent level. It is faster growing, being about i feet tall at 40 to 50 days after eutting, whereas sugarcane was only $1 \frac{1 / 2}{2}$ feet tall at that same age.

This Station does not recommend planting sugarcane for forage when 
farmers can make much better use of the land with Napier. Farmers having old sugarcane plantations can use the tops as forage for their cows, but they should use Napier grass for new plantings.

TABLE 2.-Percentage protein for each culting of Napier grass and sugarcane forage al 60- and 90-day intervals, dry basis

\begin{tabular}{l|l|l|l|l|l|l|l|l|l|l|l|l|l|}
\hline \multirow{3}{*}{ Forage } & \multicolumn{10}{|c|}{ Cutting No.- } \\
\cline { 2 - 9 } & 1 & 2 & 3 & 4 & 5 & 6 & 7 & 8 & 9 & 10 & 11 & 12 & Average \\
\hline
\end{tabular}

60-day interval

\begin{tabular}{l|l|l|l|l|l|l|l|l|l|l|l|l|l}
\hline Napier & 10.29 & 15.10 & 16.44 & 15.94 & 12.47 & 12.70 & 9.19 & 7.03 & 8.29 & 7.84 & 9.67 & 6.34 & 10.94 \\
$\begin{array}{c}\text { Sugar- } \\
\text { cane }\end{array}$ & 9.51 & 9.62 & 9.99 & 10.69 & 10.72 & 13.02 & 9.09 & 10.90 & 10.50 & 11.87 & 12.14 & 10.19 & 10.69 \\
\hline
\end{tabular}

90-day interval

\begin{tabular}{c|c|c|c|c|c|c|c|c|c|c|c|c|c}
\hline Napier & 5.76 & 6.55 & 9.95 & 8.35 & 7.57 & 5.54 & 5.80 & 5.49 & & & & & 6.88 \\
$\begin{array}{c}\text { Sugar- } \\
\text { cane }\end{array}$ & 6.69 & 8.36 & 8.61 & 8.61 & 8.57 & 7.61 & 8.92 & 8.42 & & & & & 8.22 \\
\hline
\end{tabular}

TABLE 3.-A verage dry-maller yield, in pounds, from Napier grass and sugarcane forages for the first and sccond year of cxperiment and for the 2 culting intervals

\begin{tabular}{l|c|c|c}
\hline \multirow{2}{*}{ Grass } & Year & \multicolumn{2}{|c}{ Yield for cutting interval indicated- } \\
\cline { 2 - 3 } & & 60-day & 90-day \\
\hline Napier & 1st & 22.22 & 65.53 \\
& 2nd & 51.82 & 124.70 \\
Sugarcane & 1st & 14.65 & 29.52 \\
& 2nd & 24.92 & 55.23 \\
\hline
\end{tabular}

\section{RESUMEN Y RECOMENDACIONES}

Se llevó a cabo un experimento para probar la capacidad productiva de forraje de una variedad de caña, P.R. 1010, comparada con la yerba Napier (Merker). Se usaron dos intervalos de corte, 60 y 90 días. Intervalos de 60 días entre corte y corte en promedio es lo que se recomienda para la yerba Napier.

La yerba Napier (Merker) sobrepasó, significativamente al uno por ciento, a la caña de azúcar en producción de forraje. La yerba Napier crece más rapidamente y puede alcanzar hasta cinco pies de altura entre los 40 
y 50 días después de cortada, mientras que la caña sólo llega a pie y medio a la misma edad.

La Estación no recomienda la siembra de caña de azúcar para forraje porque con la yerba Napier (Merker) los agricultores pueden hacer mucho mejor uso del terreno. Los agricultores con plantaciones viejas de caña de azúcar podrían usarlas como forraje para el ganado, pero si se disponen a sembrar predios para forraje entonces les conviene usar la yerba Napier.

\section{LITERATURE CITED}

1. Alonso Olivé, Raúl E., Estudio sobre Pastos, Forrajes, y Técnicas de su Utilización en Cuba, Asociación Nacional de Ganaderos de Cuba, La Habana, 1956.

2. Bregger, T. and Kidder, R. W., Growing Sugarcane for Forage, Univ. of Fla. Agr. Exp. Sta., Gainsville, Fla., Circ. 117, 1959.

3. Cabrera, J. I. and Rivera Brenes, L., The value of grass silage for feeding dairy cows in Puerto Rico, J. Agr. Univ. P.R. 37 (1) 59-73 1953.

4. Caro Costas, R., Vicente, J., and Figarella, J., The yields and composition of five grasses growing in the humid mountains of Puerto Rico, as affected by nitrogen, fertilization, season, and harvest procedures, J. Agr. Univ. P.R. 44 (3) 107-20 1960.

5. Rivera Brenes, L., Technical and Economic Aspects of Roughage Production in Puerto Rico, Agr. Exp. Sta., Univ. P.R., Tech. Paper 12, Sept. 1953. Río Piedras, P.R.

6. Rivera Brenes, L., Herencia, J., Arroyo, J. A., and Cabrera, J. I., Palatability trials on Merker grass (Pennisetum purpurcum), Venezuela grass (Paspalum fasciculatum), and plantain pseudostalks (Musa paradisiaca), J. Agr. Univ. P.R. 43 (4) 249-54, 1959.

7. Vázquez, Antonio E., La caña de azúcar y la química de los forrajes, Asociación de Técnicos Azucareros de Cuba, Boletín Oficial, 13 (12) La Habana, 1955.

8. Vicente, J., Rivera Brenes, L., Caro Costas, R., Rodriguez, J. P., Boneta, E., and Gracia, W., Management and utilization of the forage crops of Puerto Rico, Agr. Exp. Sta., Univ. P.R., Bul. 116, 1953. 